\title{
Pengaruh Ketergantungan dan Relationship Commitment pada Logistik Outsourcing terhadap Kinerja Operasional Perusahaan
}

\author{
Danastry, D.A, Baihaqi, I., dan Kunaifi., A \\ Manajemen Bisnis, Fakultas Bisnis dan Manajemen Teknologi, \\ Institut Teknologi Sepuluh Nopember \\ (ITS) \\ e-mail: desideriamadea@gmail.com
}

\begin{abstract}
Abstrak-Logistik merupakan proses bisnis dalam suatu perusahaan yang memberikan porsi besar pada biaya. Logistik outsourcing merupakan perusahaan pihak ketiga yang dipercaya oleh perusahaan untuk melakukan sebagian atau keseluruhan proses logistik pada suatu perusahaan. Kebijakan dalam menggunakan logistik outsourcing pada suatu perusahaan akan sangat berpengaruh terhadap efisiensi perusahan. Ketergantungan serta relationship commitment perusahaan kepada perusahaan logistik outsourcing menjadi sangat penting untuk diperhatikan. Penggunaan logistik outsourcing akan dapat mempengaruhi kinerja operasional perusahaan. Survey dilakukan kepada 53 perusahaan yang bergerak dibidang manufaktur, distributor, dan retailer yang menggunakan jasa logistik outsourcing. Penelitian ini bertujuan untuk menganalisis pengaruh dari ketergantungan dan relationship commitment pada perusahaan yang menggunakan logistik outsourcing terhadap kinerja operasional perusahaan. Analisis regresi digunakan untuk menguji hipotesis terkait hubungan antara ketergantungan, relationship commitment, logistik outsourcing dan kinerja operasional perusahaan. Hasil dari penelitian ini menunjukkan bahwa ketergantungan tidak berpengaruh terhadap penggunaan logistik outsourcing, sedangkan hubungan dengan logistik outsourcing berpengaruh serta penggunaan logistik outsourcing dapat mempengaruhi kinerja operasional perusahaan.
\end{abstract}

Kata Kunci-Ketergantungan, Komitmen Kerjasama, Logistik Outsourcing, Kinerja Operasional.

\section{PENDAHULUAN}

S ISTEM logistik yang ada di Indonesia dipengaruhi dengan adanya sistem logistik nasional (sislognas). Berdasarkan peraturan Presiden no 26/2012, Sislognas memiliki peran dalam mensinkronkan dan menyelarasakan kemajuan antar sektor ekonomi dan antar wilayah untuk menumbuhkan ekonomi yang inklusif dan menjadi benteng bagi ketahanan ekonomi nasional. Saat ini, kinerja sistem logistik di Indonesia masih belum optimal yang disebabkan masih tingginya biaya logistik nasional yang mencapai kurang lebih $27 \%$ dari produk domestik bruto (PDB). Dibandingkan dengan Negara lain, biaya logistik di Indonesia relatif tinggi. Biaya logistik di Amerika, Inggris dan Jerman mencapai angka berkisar $8 \%$ hingga 9\%. Pada penjualan produk-produk retail (customer goods), di Indonesia biaya untuk logistik menyerap $40 \%$ dari harga jual produk retail dimana biaya transportasi menyerap biaya terbesar pada logistik [1]. Tingginya biaya logistik di Indonesia, maka keputusan untuk melakukan outsourcing pada proses logistik merupakan keputusan yang tepat, sehingga perusahaan dapat berfokus pada core bisnis perusahaan.

Dalam penggunaan logistik outsourcing, perusahaan harus memiliki kepercayaan kepada perusahaan penyedia logistik. Kepercayaan perusahaan kepada jasa logistik dapat ditingkatkan dengan adanya kerjasama yang baik antar kedua pihak. Penggunaan logistik pada suatu perusahaan diharapkan mampu untuk meningkatkan kinerja operasional bagi perusahaan. Proses logistik menjadi penting dilakukan oleh perusahaan karena berkaitan dengan biaya produksi yang dikeluarkan oleh perusahaan. Dalam upaya untuk memaksimalkan penggunaan logistik outsourcing pada suatu perusahaan, relationship commitment dan ketergantungan merupakan hal yang perlu diperhatikan oleh perusahaan pengguna jasa logistik.

Mempercayakan suatu proses bisnis pada perusahan eksternal akan menimbulkan resiko bagi perusahaan. Oleh karena itu dibutuhkan adanya suatu komitmen bagi kedua perusahaan baik perusahaan pengguna jasa outsourcing

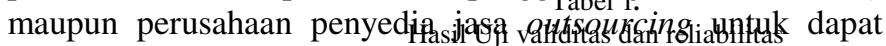

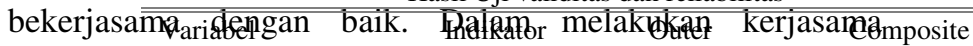
dibutuhkan adanya kepercayaan. Tinggidyrg tinglRatliability kepercayaan suatulgperusahaanSRepada perusaథi3an eksternal 0.868

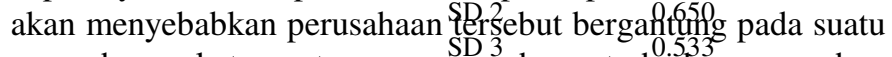
perusahaan, ketergantungan pSD 3 S 3 ahaan terha.jag perusahan lain tersebut akan menyebabkąplinerja yang. ditiberikan oleh perusahaan logistik outsourcingDberkurang. S.ełsingga sistem logistik dan keputusan penggufian logistik ou 98 burcing yang dilakukan oleh perusahaan menGPR untuk dilak $8 k a n$ penelitian

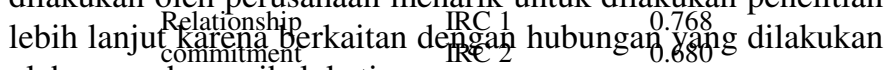
oleh perusahaan pihak ketiga. NRC $1 \quad 0.593$ NRC $2 \quad 0.578$ NRC $3 \quad 0.678$

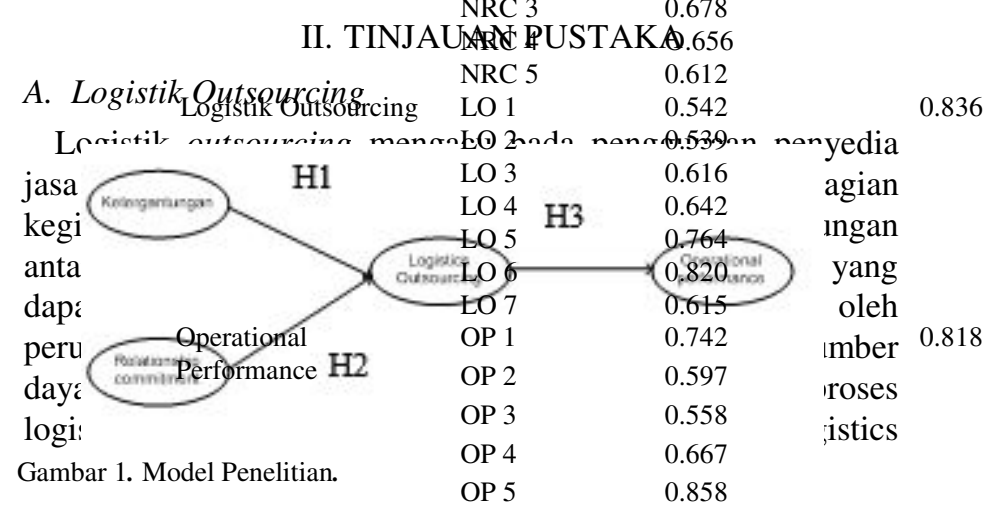


outsourcing mencakup berbagai layanan seperti perancanaan, pelaksanaan dan pengendalian bahan baku dan informasi

Logistik outsourcing dibedakan kedalam 4 golongan yaitu Logistics service providers (LSP), Thrid-party Logistics (3PL), Lead Logistics Provider (LLP), fourth-party Logistics providers (4PL). LSP merupakan perusahaan yang menyediakan jasa logistik tradisional seperti transportasi dan pergudangan. 3PL merupakan penggunaan dua atau lebih aktivitas logistic yang didelegasikan kepada perusahan jasa logistik [3]. LLP adalah perusahaan 3PL yang tidak memiliki asset sendiri serta memiliki keunggulan integrasi teknologi 3PL yang dikombinasikan dengan biaya overhead yang rendah. 4PL merupakan perusahaan jasa logistik yang bertanggung jawab atas perencanaan, penyusunan, dan integrasi operasi dan disaat yang sama juga mengontrol optimasi fisik, keuangan dan distribusi yang biasanya dilakukan oleh perusahaan 3PL.

\section{B. Operational Performance}

Kinerja operasional didefinisikan sebagai dimensi strategis perusahaan yang digunakan sebagai competitive advantage pada suatu perusahaan. Kinerja operasional tersebut dapat diukur dengan beberapa indikator yang digunakan, diantaranya adalah kualitas, delivery, fleksibility dan cost. Kinerja operasional sebagai bagian dari kinerja organisasi yang berfokus pada cost efficiency, productivity, dan profitability perusahaan [4]. Operational performance juga didefinisikan sebagai kinerja yang baik pada produksi, pemasaran dan manajemen pada suatu perusahaan yang akan memberikan competitive advantage perusahaan [5]. Kinerja operasional dapat diukur dengan dengan pelayanan yang diberikan oleh perusahaan kepada konsumen, kecepatan waktu pengiriman, ketepatan pengiriman, product volume flexibility, product mix flexibility, new product flexibility [6].

\section{III.MODEL PENELITIAN}

Penelitian mengembangkan penelitian yang sebelumnya telah dilakukan oleh Hou dimana penelitian tersebut melakukan penelitian terkait ketergantungan dan relationship commitment pada logistik outsourcing terhadap service quality. Pada penelitian ini, juga mengembangkan penelitian yang dilakukan oleh Liu, et al. dimana operasional performance digunakan sebagai variabel dependen yang dipengaruhi oleh ketergantungan, relationship commitment dan logistik outsourcing. Model penelitian yang digunakan dalam penelitian ini ditampilkan pada Gambar 1 .

Mengacu pada penelitian yang dilakukan oleh Hou dan Liu, maka dikembangkan hipotesis dalam penelitian ini yaitu:

H1: Ketergantungan terhadap perusahaan jasa logistik memiliki pengaruh positif signifikan terhadap logistik outsourcing yang digunakan oleh perusahaan

H2: Relationship commitment dengan jasa logistik memiliki pengaruh positif signifikan terhadap logistik outsourcing yang digunakan oleh perusahaan.

H3: Penggunaan logistik outsourcing berpengaruh positif signifikan terhadap operational performance perusahaan

\section{METODOLOGI PENELITIAN}

\section{A. Pengumpulan Data}

Tabel 2.

Hasil uji hipotesis

\begin{tabular}{llll}
\hline \hline Hipotesis & T-statistik & Signifikan & Hasil \\
\hline $\begin{array}{l}\text { H1: Ketergantungan } \rightarrow \\
\text { Logistik Outsourcing } \\
\text { Relationship commitment } \rightarrow\end{array}$ & 0.766 & 0.447 & Ditolak \\
$\begin{array}{l}\text { Logistik Outsourcing } \\
\text { Logistik outsourcing } \rightarrow \\
\text { operational performance }\end{array}$ & 1.811 & 0.076 & Diterima \\
\hline \hline
\end{tabular}

Data yang digunakan dalam penelitian ini adalah data primer yaitu data hasil penyebaran kuesioner yang dilakukan pada perusahaan yang bergerak pada industri manufaktur, distribusi dan retailer yang berlokasi di Surabaya, Sidoarjo dan Gresik. Daftar perusahaan yang akan digunakan sebagai responden didapatkan dari website yang dimiliki oleh Kementrian Perindustrian Republik Indonesia. Peneliti juga mendatangi secara langsung perusahaan yang digunakan sebagai responden.

Dimensi pengukuran yang digunakan untuk mengukur ketergantungan, relationship commitment dan logistik outsourcing diadaptasi dari penelitian Hou et al. Sedangkan dimensi pengukuran yang digunakan untuk mengukur kinerja operasional diadaptasi dari penelitian Liu et al. Skala yang digunakan dalam kuesioner menggunakan skala likert 7 poin.

Penelitian ini menggunakan desain snowball sampling. Sampel penelitian ini adalah perusahaan manufaktur, distribusi dan retailer yang menggunakan logistik outsourcing dalam menjalankan proses bisnisnya. Perusahaan tersebut di Surabaya, Sidoarjo dan Gresik. Proses pengisian kuesioner diwakili oleh manajer atau staff logistik pada suatu perusahaan. Kuisioner diberikan kepada 112 calon responden dan terdapat total 53 kuesioner yang kembali.

Analisis pada penelitian ini terdiri dari analisis deskriptif demografi, dan analisis regresi yang digunakan untuk mengembangkan dan membangun hipotesis penelitian, memprediksi situasi yang kompleks, menguji hubungan prediktif antar variabel,yang diteliti.

\section{ANALISIS DAN PEMBAHASAN}

\section{A. Validitas dan Reliabilitas}

Uji validitas dan reliabilitas pada penelitian ini dilakukan dengan menggunakan Partial Least Squares (PLS). uji validitas dengan menggunakan PLS dilihat dari nilai convergent validity. Nilai convergent validity ditunjukkan pada tabel 1. Indikator dikatakan telah memenuhi convergent validity apabila nilai outer loading dari tiap indikator lebih besar dari 0,5. Hasil evaluasi menunjukkan bahwa seluruh indikator dan variabel telah memenuhi convergent validity.

Evaluasi kedua pada outer model adalah discriminant validity dimana untuk mengukurnya dapat menggunakan nilai cross loading. Suatu indikator dikatakan memenuhi 
discriminant validity jika nilai cross loading indikator terhadap variabelnya adalah yang terbesar dibandingkan variabel lainnya. Hasil menunjukkan bahwa seluruh indikator dan variabel yang digunakan dalam penelitian telah memenuhi diskriminant validity. Evaluasi ketiga yang digunakan adalah Composite reliability. Composite reliability digunakan untuk menguji reliabilitas indikator-indikator pada setiap variabel penelitian. Suatu variabel dikatakan telah memenuhi composite reliability jika memiliki nilai lebih besar dari 0,7. Hasil menunjukkan bahwa masing-masing variabel pada penelitian ini telah memenuhi kriteria composite reliability. (Tabel 1)

\section{B. Uji Hipotesis}

Dalam penelitian ini, uji hipotesis dilakukan dengan menggunakan regresi. Uji Hipotesis dilakukan dengan menggunakan uji korelasi ganda (R), uji koefisien determinasi $\left(\mathrm{R}^{2}\right)$, dan uji parsial $(\mathrm{T})$. Regresi linier berganda digunakan untuk mendapatkan nilai dari hubungan ketergantungan dan relationship commitment terhadap logistik outsourcing. Nilai $\mathrm{R}$ pada hasil regresi berfungsi untuk menunjukkan kuat hubungan antar variabel. Nilia $R$ pada regresi berganda sebesar 0.434 yang berarti memiliki nilai yang sedang. Nilai $\mathrm{R}^{2}$ pada hasil regresi berganda sebesar $18,8 \%$ yang berarti ketergantungan dan relationship commitment dapat mempengaruhi logistik outsourcing sebesar $18.8 \%$, sedangkan sisanya dipengaruhi oleh faktor lain.

Regresi linier sederhana digunakan untuk mendapatkan nilai dari hubungan logistik outsourcing terhadap kinerja operasional. Nilai $\mathrm{R}$ pada hasil regresi berfungsi untuk menunjukkan kuat hubungan antar variabel. Nilia $R$ pada regresi linier sederhana sebesar 0.464 yang berarti memiliki nilai yang sedang. Nilai $\mathrm{R}^{2}$ pada hasil regresi linier sederhana sebesar $21.5 \%$ yang berarti logistik outsourcing dapat mempengaruhi kinerja operasional sebesar $21.5 \%$, sedangkan sisanya dipengaruhi oleh faktor lain.

Pengujian hipotesis dilakukan dengan melihat nilai signifikan $\mathrm{T}$ pada hasil regresi. Hipotesis dapat diterima jika nilai signifikannya lebih kecil dari 0,1 . Hasil uji hipotesis ditampilkan pada Tabel 2.
Variabel ketergantungan tidak berpengaruh terhadap penggunaan logistik outsourcing perusahaan. Hal tersebut disebabkan karena pertumbuhan jasa penyedia logistik di Indonesia yang berkembang pesat, sehingga perusahaan dengan mudah beralih pada perusahaan jasa logistik lain. Perjanjian atau kontrak dengan perusahaan penyedia jasa logistik dibutuhkan oleh perusahaan untuk mempertahankan kerjasama dalam jangka panjang. Hal tersebut dibutuhkan oleh perusahaan untuk meningkatkan kinerja bagi perusahaan yang menggunakan logistik outsourcing

Penggunaan jasa penyedia logistik outsourcing pada suatu perusahaan akan dapat meningkatkan kinerja operasional suatu perusahaan. hal tersebut disebebkan karena dengan menggunakan outsourcing logistik, perusahaan akan lebih focus pada proses inti pada perusahaan dan mampu meningkatkan sistem informasi logistik pada suatu perusahaan. Pada penelitian ini, Variabel ketergantungan dan relationship commitment mampu mempengaruhi logistik outsourcing sebesar $18.8 \%$. Oleh karena itu penelitian selanjutnya dapat lebih mengeksplor faktor-faktor lain yang dapat mempengaruhi logistik outsourcing

\section{DAFTAR PUSTAKA}

[1] H. T. Asworo, "Bisnis Indonesia," Bisnis Indonesia Industri, 2017. [Online]. Available: http://industri.bisnis.com. [Accessed: 29-Jun2017].

[2] H. Hsiao, R. Kemp, V. Vors, and S. Omta, "A Classification of Logistics Outsourcing Levels and Their Impact of Service Performance: Evidence from the Food Processing Industry," Int. J. Prod. Econ., vol. 124, pp. 75-86, 2010.

[3] B. Huo, C. Liu, M. Kang, and X. Zhao, "The impact of dependance and relation commitment on logistics outsourcing," Int. J. Phys. Distrib. Logist. Manag., vol. 45, pp. 887-912, 2015.

[4] B. Jiang, G. V. Frazier, and E. L. Prater, "Outsourcing Effects on Firm Operational Performance an Empirical Study," Int. J. Oper. Prod. Manag., vol. 26, no. 12, pp. 1280-1300, 2006.

[5] G. N. Kenyon and P. H. Westfall, "Production outsourcing and operational performance: An empirical study using secondary data," Int. J. Prod. Econ., 2015.

[6] C. Liu, B. Huo, S. Liu, and X. Zhao, "Effect of Information Sharing and Process Coordination on Logistics Outsourcing," Ind. Manajement Data Syst., vol. 115, no. 1, pp. 41-63, 2015.

\section{KESIMPULAN}

